động DLS và nhu cầu tuyển dụng tại các bệnh viện ở tỉnh Bình Thuận. Kết quả chỉ ra tình trạng thiếu hụt DSLS ở tỉnh Bình Thuận, đặc biệt là những người có trình đô học vấn cao, nguyên nhân có thể là do thu nhập thấp. Nghiên cứu đề xuất rằng các bệnh viện nên hồ trợ về thu nhập như lương, trợ cấp nghề nghiệp để thu hút nhiều dược sĩ là công tác DLS hơn và liên tục nâng cao chuyên môn của họ cho công việc. Ngoài ra, kết quả của nghiên cứu này có thể được sử dụng để hỗ trợ cho báo cáo của Sở Y tế tỉnh Bình Thuận gửi Bộ $Y$ tế và đề xuất các chính sách ngắn hạn và dài hạn nhằm cải thiện thực hành dược lâm sàng ở Việt Nam.

\section{TÀI LIÊU THAM KHẢO}

1. Pawłowska, I., et al., Clinical and conventional pharmacy services in Polish hospitals: a national survey. Int J Clin Pharm, 2016. 38(2): p. 271-9.

2. Sở Y tế tỉnh Bình Thuận. Hiện trạng khám chữa bênh tỉnh Bình Thuân năm 2017. 2018 [cited 2019 6/6]; Available from: http:// syt.binhthuan.gov.vn/ wps/portal/binhthuan/ trangchu/!ut/p/c5/ 04_SB8K8xLLM9MSSzPy8xBz9CP0os3gfDxCLQ2MD Q09_Xy9XA0f3ED8nswB3YzNLQ_1wkA48Kowg8gY 4gKÖBvp9Hfm6qfkF2dpqjo6IiAO-

LHHI!/dl3/d3/L2dBISEvZOFBIS9nQSEh/.

3. Ủy ban Nhân dân tỉnh Bình Thuận, Quyết định số 2881/QĐ-UBND về quy hoạch phát triển Ngành Y tế tỉnh Bình Thuân đến năm 2020 2011, ngày 29 tháng 12 năm 2011: Bình Thuận.

4. Bệnh viện đa khoa Cái Nước. Nghiên thực trạng nhân lực dược tại các cơ sở y tế công lập tỉnh Cà Mau nẳm 2013 và nhu câu đến năm 2016. 2014 [cited 11/10/2020; Available from: http:// cainuochospital.com/ nghien-cuu-thuc-trang-nhanluc-duoc-tai-cac-co-so-y-te-cong-lap-tinh-ca-maunam-2013-va-nhu-cau-den-nam-2016.html.

5. Vo, T.-H., et al., Pharmacy Education in Vietnam. Vol. 77. 2013. 114.

6. Trinh, H.T., et al., Hospital clinical pharmacy services in Vietnam. Int J Clin Pharm, 2018. 40(5): p. $1144-1153$.

\title{
TÁC DỤNG GÂY HOẠI TỬ TẾ BÀO UNG THƯ CỦA VIRUS VACCIN SỞI VÀ NIMOTUZUMAB
}

\author{
Cấn Văn Mão', Lê Mạnh Cường ${ }^{2}$, Hồ Anh Sơnn ${ }^{1}$
}

\section{TÓM TẮT}

Mục tiêu: Đánh giá hiệu quả virus vaccin sởi (MeV) và Nimotuzumab gây chết kiểu hoại tử trên tế bào ung thư. Đối tượng và phương pháp: Sử dụng MeV và Nimotuzumab gây chết tế bào ung thư Hep2. Tế bào Hep2 tiếp xúc MeV và Nimotuzumab được thu thập ở thời điểm 48 giờ, 72 giờ, 96 giờ để đánh giá bằng kỹ thuât flow cytometry. Kết quả: Tỉ lệ tế bào chết kiểu hoại tử ở các nhóm điều trị nhiêu hơn có nghĩa thống kê so với nhóm chứng, thời điểm 96h, kết hợp MeV và Nimotuzumab gây chết tế bào ung thư kiểu hoại tử nhiều hơn so với dùng đơn. Kết luận: kết hợp virus vaccine sởi và Nimotuzumab có tác dụng gẩy chết tế bào Hep2 kiểu hoại tử nhiêuu hơn dùng đơn virus vaccine sởi hoặc Nimotuzumab.

Ti̛ khóa: Ung thư đầu cổ, virus vaccine sởi, Nimotuzumab, chết hoại tử

\section{SUMMARY \\ NECROSIS EFFECTS OF VACINE-STRAIN \\ MEASLES VIRUS AND NIMOTUZUMAB ON CANCER CELLS}

Objectives: This study aims to evaluate of

\footnotetext{
${ }^{1}$ Học viện Quân y

${ }^{2}$ Bềnh viên YHCT Trung ương

Chịu trách nhiệm chính: Hồ Anh Sơn

Email: hoanhsonhp@gmail.com

Ngày nhận bài: 11/11/2020

Ngày phản biện khoa học: 3/12/2020

Ngày duyệt bài: 16/12/2020
}

necrosis effects of vacine-strain measles virus (MeV) and Nimotuzumab against cancer cells. Materials and methods: MeV and Ninotuzumab were used to induce necrosis on Hep2 cancer cells. Hep2 cells treated with MeV and Nimotuzumab were collected at 48, 72 hours and 96 hours to perform flow cytometry. Results: the proportion of necrosis cells in treated groups was significantly higher than control group. $\mathrm{MeV}$ and Nimotuzumab combination induced higher rate of necrosis cells than thouse in single treatment groups. Conclusion: MeV and Nimotuzumab combination increases necrosis on head and neck cancer Hep2 cells than single MeV or Nimotuzumab treatment.

Keywords: head and neck squamous-cell carcinoma, measles virus vaccine, Nimotuzumab, necrosis.

\section{I. ĐĂT VẤN ĐỀ}

Ung thư đầu cổ là một nhóm bệnh ung thư xuất phát từ những vị trí khác nhau ở đường hô hấp và tiêu hoá trên. Những ung thư này có nhiều điểm chung về sinh bệnh học, dịch tễ, lâm sàng và điều trị. Hầu hết các khối u ác tính vùng đầu cổ xuất phát từ biểu mô bề mặt nên có tới hơn $90 \%$ số trường hợp là ung thư biểu mô tế bào vảy hoặc các biến thể của nó. Hơn $90 \%$ ung thư đầu cổ có bộc lộ thụ thể tăng trưởng biểu bì (EGFR), liên quan tới tình trạng đáp ứng kém với hóa, xạ trị1. EGFR thường biểu hiện quá mức và đóng vai trò quan trọng trong bênh sinh của ung thư đầu cổ. Đặc biệt, sự biểu hiện của EGFR tăng cao trong các khối u trong giai đoạn tiến 
triển 1 , hoặc trong các khối u kém biệt hóa 2 . Nimotuzumab là kháng thể đơn dòng đặc hiệu với EGFR, đã được chứng minh có hiệu quả trong điều trị HNSCC trong các nghiên cứu trong và ngoài nước 3,4.

Ngoài liệu pháp sử dụng kháng thể đơn dòng để điều trị ung thư đầu cổ, sử dụng virus ly giải tế bào ung thư (OLV) đang là hướng đi mới. OLV là virus có khả năng xâm nhập vào tế bào khối ung thư có chọn lọc, tự sao chép, nhân lên, giải phóng khỏi tế bào trực tiếp ly giải các tế bào đích ung thư. Trong số OLV, virus vaccine sởi (MeV) cho thấy khả năng phân giải tế bào ung thư in vitro, trên chuột thiếu hụt miễn dịch mang khối ung thư người và đang tiến hành các thử nghiệm lâm sàng trên người 5,6,7.

Nghiên cứu của chúng tôi bước đầu đánh giá hiệu quả của việc kết hợp $M e V$ và Nimotuzumab trong việc gây hoại tử (necrosis) tế bào ung thư đầu cổ người Hep2 in vitro.

\section{II. ĐỐI TƯợNG VÀ PHƯƠNG PHÁP NGHIÊN CỨU}

2.1. Đối tượng, vật liệu nghiên cứu. Tế bào ung thư biểu mô vảy đầu cổ người Hep-2 (ATCC CCL-23, laryngeal SCC) được cung cấp bởi công ty ATCC (American Type Culture Collection, P.O. Box 1549, Manassas, VA 20108 USA) được bảo quản tại labo nghiên cứu ung thư của Bộ môn Sinh lý bệnh - Học viện Quân y.

Virus vaccine Sởi (MeV) chủng Edmonton được phân lập, tăng sinh từ vaccine Priorix (GlaxosmithKline, Anh).

Chế phẩm kháng thể đơn dòng Nimotuzumab được nhập khẩu từ $\mathrm{Cu} B \mathrm{Ba}$, dưới tên CIMAher, hàm lượng $5 \mathrm{mg} / \mathrm{ml}$.

Bộ kit PE Annexin V Apoptosis Detection kit $(\mathrm{BD})$, môi trường nuôi cây tế bào và các dụng cụ, hóa chất tiêu hao khác.

\subsection{Phương pháp nghiên cứu}

2.2.1. Thiết kế nghiên cứu. Nghiên cứu được thiết kế là nghiên cứu thực nghiệm, mô tả cắt ngang có đối chứng.

2.2.2. Các kỹ thuật sử dụng trong nghiên cứu

- Kỹ thuật nuôi cấy các dòng tế bào ung thư: Tế bào thận khỉ (Vero cells) được nuôi bằng môi trường M199, phục vụ cho mục đích tăng sinh virus. Tế bào Hep2 được nuôi cấy trên chai nuôi cây tế bào có bổ sung $10 \%$ FBS, $1 \%$ Penicillin và Streptomycin, nhiệt độ $37^{\circ} \mathrm{C}, \mathrm{CO}_{2} 5 \%$. Thu tế bào Hep2 bằng Trypsin EDTA, sau đó li tâm để loại bỏ môi trường thu tế bào.

Chuẩn bị tế bào Hep2: Chuẩn đô để được dung dịch tế bào có nồng độ $10^{5}$ tế bào $/ \mathrm{ml}$. Tiến hành cho $3 \mathrm{ml}$ dung dich tế bào trên vào mỗi giếng trên 6 phiến 6 giếng, ủ trong tủ ấm $37^{\circ} \mathrm{C}$, $5 \% \mathrm{CO}_{2}$. Sau 24 giờ, tế bào bám đáy, thay môi trường nuôi cấy với từng nhóm như sau: Nhóm chứng: $3 \mathrm{ml}$ môi trường nuôi cấy mới; Nhóm MeV: môi trường nuôi cấy có bổ sung $\mathrm{MeV}$ liều MOI $=1$; Nhóm Nimotuzumab: môi trường nuôi cây có bổ sung Nimotuzumab nồng độ $100 \mu \mathrm{g} / \mathrm{ml}$; Nhóm MeV+Nimotuzumab: môi trường nuôi cấy có bổ sung $\mathrm{MeV}$ liều $\mathrm{MOI}=1$ và Nimotuzumab nồng độ $100 \mu \mathrm{g} / \mathrm{ml}$.

Sau 48, 72 và 96 giờ sau tiếp xúc với $M e V$ và Nimotuzumab, tiến hành thu tế bào để chạy flow cytometry. Kỹ thuật phân tích tế bào dòng chảy đánh giá tế bào chết: sử dụng kháng thể kháng Annexin $V$ gắn với tác nhân phát huỳnh quang $P E$ và chất nhuộm nhân tế bào $7 A A D$ (có dải sóng kích thích/phát xạ trùng với PerCP-Cy5-5A). Tế bào được xử lý và nhuộm theo quy trình và hóa chất của bộ kit $\mathrm{PE}$ Annexin $\mathrm{V}$ Apoptosis Detection kit (BD).

Đánh giá tỉ lệ tế bào chết hoại tử (necrosis) trên hệ thống FACS CANTO 2 (BD): xác định quần thể tế bào cần đánh giá, xác định vùng giá trị huỳnh quang (PE và PerCP) âm tính, xác định tỉ lệ tế bào chết apoptosis, hoại tử. Tín hiệu $\mathrm{PE}$ cho thấy sự biểu hiện của Anexin V. Tín hiệu của PerCP-Cy5-5A cho thấy sự biểu hiện của 7AAD. Số tế bào chết necrosis sẽ là tổng của vùng Q3.

2.3. Xử lý thống kê: So sánh trung bình của 2 nhóm độc lập bằng T-test, so sánh trung bình của 3 nhóm bằng phân tích phương sai ANOVA. Số liệu được xử lý bằng phần mềm SPSS 20.0 và GraphPad Prism 6. Sự khác biệt có ý nghĩa thống kê khi $p<0,05$.

\section{KẾT QUẢ NGHIÊN CỨU}

\subsection{MeV gây chết tế bào necrosis tăng} theo thời gian

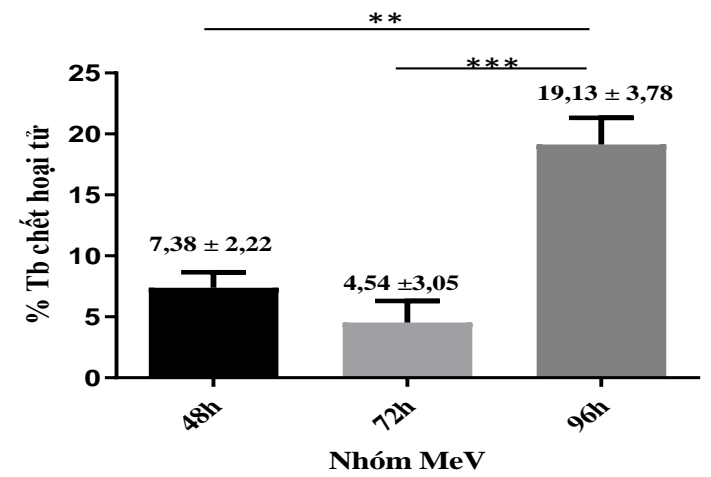

Hinh 3.1. So sánh tỉ lệ tế bào chết hoại tử theo thời gian điều trị bằng MeV

$* *: p<0,01 ; * * *$ : $p<0,001$ 
Kết quả tỉ lệ tế bào chết hoại tử ở các mẫu theo thời gian điều trị bằng $\mathrm{MeV}$, tỉ lệ tế bào chết hoại tử đạt mức thấp nhất ở thời điểm 72 giờ và cao nhất ở thời điểm 96 giờ, sự khác biệt này có ý nghĩa thống kê (48 giờ là $7,38 \pm 2,22 ; 72$ giờ là $4,54 \pm 3,05 ; 96$ giờ là $19,13 \pm 3,78$ với $\mathrm{p}$ (72 giờ48 giờ) $=0,303 ; \mathrm{p}$ (72 giờ-96 giờ) $=0,001 ; \mathrm{p}$ (48 giờ-96 giờ) $=0,003)$ (hình 3.1).

3.2. Nimotuzumab gây chết tế bào necrosis tại các thời điểm nghiên cứu

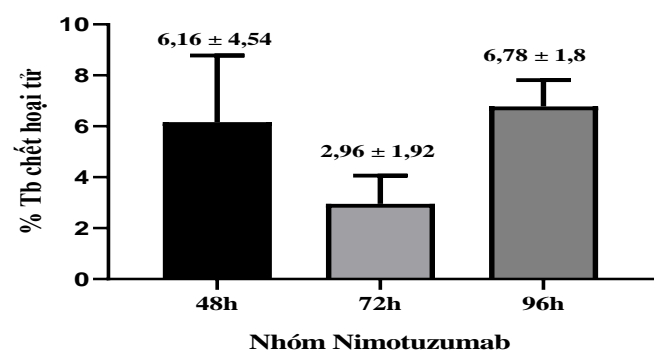

Hình 3.2. So sánh tỉ lệ tế bào chêt hoại tử theo thời gian điều trị bằng Nimotuzumab

Kết quả tỉ lệ tế bào chết hoại tử ở các mẫu theo thời gian điều trị bằng Nimotuzumab, tỉ lệ tế bào chết hoại tử cũng đạt mức thấp nhất ở thời điểm 72 giờ và cao nhất ở thời điểm 96 giờ, tuy nhiên sự khác biệt này chưa có ý nghĩa thống kê $(p>0,05)$ (hình 3.2).

3.3. Kết hợp MeV và Nimotuzumab gây chết tế bào necrosis

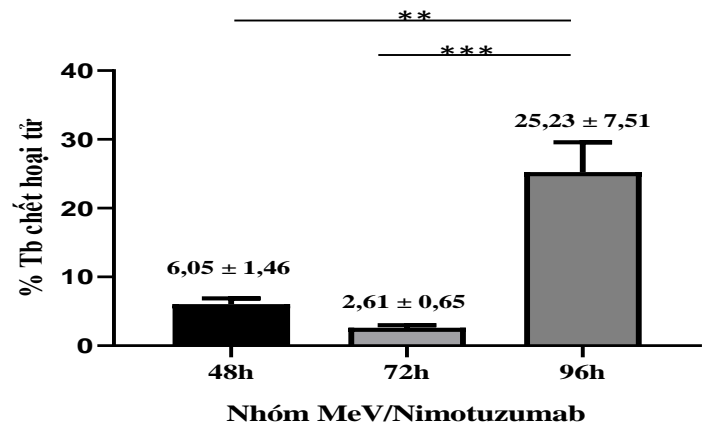

Hình 3.3. So sánh tỉ lệ tế bào chêt hoại tử theo thời gian điều trị bằng MeV và Nimotuzumab

$$
* *: p<0,01 ; * * *: p<0,001
$$

Kết quả tỉ lệ tế bào chết hoại tử ở các mẫu theo thời gian điều trị bằng $\mathrm{MeV}$ và Nimotuzumab, tỉ lệ tế bào chết hoại tử cũng đạt mức thấp nhất ở thời điểm 72 giờ và cao nhất ở thời điểm 96 giờ, sự khác biệt này có ý nghĩa thống kê (48 giờ là $6,05 \pm 1,46 ; 72$ giờ là $2,61 \pm$ 0,$65 ; 96$ giờ là $25,23 \pm 7,51$ với $\mathrm{p}$ (72 giờ-48 giớ) $=$ 0,$\left.378 ; \mathrm{p}_{\text {(72 giờ-96 giờ) }}=0,001 ; \mathrm{p}_{\text {(48 giơ-96 giơ) })}=0,002\right)$ (hình 3.3).
3.4. Tế bào Hep 2 chết necrosis ở thời điểm 96 giờ tại các nhóm nghiên cứu

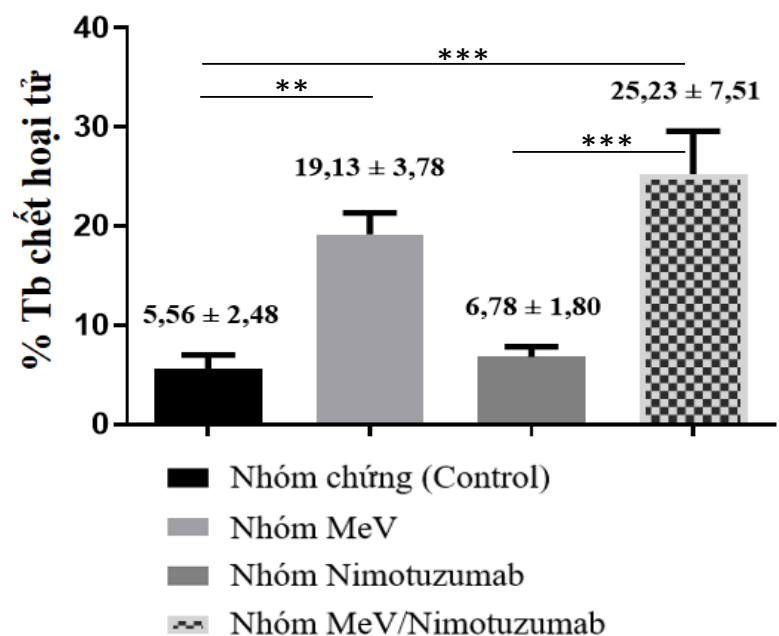

Hinh 3.4. Kêt quả chạ flow cytometry tế bào Hep2 ở thời điểm 96 giờ sau điều trị bằng MeV và Nimotuzumab

$* *$ : $p<0,01 ; * * *$ : $p<0,001$

ở thời điểm 96 giờ, tỷ lê tế bào chết hoại tử ở các nhóm điều trị MeV (nhóm MeV và nhóm phối hợp) đều tăng cao hơn có ý nghĩa thống kê so với nhóm chứng (MeV là 19,73 $\pm 3,78 ; \mathrm{MeV}+$ Nimotuzumab là $25,23 \pm 7,51$ so với và nhóm chứng là 5,56 $\pm 2,48$; lân lượt $\mathrm{p}(\mathrm{MeV}$-Control $)=$ 0,$006 ; \mathrm{p}(\mathrm{MeV}+$ Nimotuzumab -Control $)=$ 0,001 ) (hình 3.4).

\section{BÀN LUÂ̂N}

MeV có khả năng ly giải tế bào ung thư thông qua hai cơ chế chính: (1) cơ chế trực tiếp giết chết tế bào $u$ qua hình thành hợp bào (tế bào khổng lồ nhiều nhân) và (2) ly giải tế bào u qua trung gian kích thích miễn dịch đặc hiệu kháng u. Hai cơ chế này đã được chứng minh là có hiệu quả điều trị tế bào khối u người trong các nghiển cứu in vitro và in vivo 5,8 .

Để tăng cường hiệu lực điều trị của các OLV người ta nghĩ tới việc kểt hợp OLV với các liệu pháp khác như: kết hợp với hóa trị, xạ trị, liệu pháp miễn dịch. Một số thử nghiệm kết hợp Oncolytic virus với với liệu pháp miến dịch: MeV kết hợp yếu tố kích thích bạch câu hạt (GM-CSF) điều trị cho chuột mang khối u tế bào lympho $B$, ung thư biểu mổ đại tràng đã làm tăng đáng kể mức độ thoái triển khối u hay làm chậm quá trình phát triển khối $u$, có tương quan với sự gia tăng số lượng tế bào bạch cầu hạt trung tính và thâm nhiễm tế bào lympho T CD3+ của vật chủ vào khối u. Các thử nghiệm tiền lâm sàng sử dụng $\mathrm{MeV}$ có khả năng nhắm mục tiêu là EGFR 
để xâm nhập và ly giải tế bào ung thư nguyên bào thần kinh và thử nghiệm lâm sàng với đối tượng là tế bào ung thư đầu cổ. Các thử nghiệm đều cho thấy khả năng ức chế và gây chết tế bào ung thư của MeV nhắm muc tiêu EGFR trên cả in vitro và trên mô hình chuột thiếu hụt miễn dịch mang các khối ung thư người nói trên (in vivo).

Từ những cơ sở lý luận và thực tiễn trên, chúng tôi tiến hành kết hợp MeV với kháng thể đơn dòng Nimotuzumab nhằm mục đích cộng hợp tác dung điều trị ung thư theo cơ chế của hai liệu pháp trên để có thể đem lai hiệu quả tốt trong điêu trị ung thư biểu mô tể bào vảy đầu cổ. Kết quả nghiên cứu của chúng tôi cho thây hiệu quả gây hoại tử tế bào ung thư đầu cổ của sư kết hợp điều trị MeV+Nimotuzumab cao hơn đáng kể so với điều trị đơn với $\mathrm{MeV}$ hoặc Nimotuzumab in vitro.

\section{KẾT LUÂN}

Kết hợp $M e V$ và Nimotuzumab gây chết kiểu hoại tử đối với tế bào Hep2 nhiều hơn có ý nghĩa thổng kê so với điều trị đơn $\mathrm{MeV}$ hoặc Nimotuzumab và nhóm chứng.

\section{TÀI LIÊU THAM KHẢO}

1. Grandis JR T.D. (1993). Elevated levels of transforming growth factor alpha and epidermal growth factor receptor messenger RNA are early markers of carcinogenesis in head and neck cancer. Cancer Res., 53:3579-3584.

2. Alterio D., Marvaso G., Maffini F., et al. (2017). Role of EGFR as prognostic factor in head and neck cancer patients treated with surgery and postoperative radiotherapy: proposal of a new approach behind the EGFR overexpression. Med Oncol., 34(6): 107.

3. Sundaram S V.B., Sridharan $\mathbf{N}$ and Poojar K. (2015). Nimotuzumab with induction chemotherapy and chemo radiation in patients with advanced head and neck cancer. J Cancer., Ther 6:146 - 152.

4. Nguyễn Thị Thái Hòa (2015). Đánh giá kết quả điều trị kết hợp kháng thể đơn dòng Nimotuzumab - hóa xạ trị ung thư biểu mô vảy vưng đầu cổ giai đoạn lan tràn tại vùng, Luận án tiến sĩ y học, Trường Đại học Y Hà Nội.

5. Galanis E., Atherton P.J., Maurer M.J., et al. (2015). Oncolytic measles virus expressing the sodium iodide symporter to treat drug-resistant ovarian cancer. Cancer Res., 75(1):22-30.

6. Russell S.J., Federspiel M.J., Peng K.W., et al. (2014). Remission of disseminated cancer after systemic oncolytic virotherapy. Mayo Clin Proc., 89(7):926-933.

7. Son H.A., Zhang L., Cuong B.K., et al. (2018). Combination of Vaccine-Strain Measles and Mumps Viruses Enhances Oncolytic Activity against Human Solid Malignancies. Cancer Invest., 36(2):106-117.

8. Galanis E., Hartmann L.C., Cliby W.A., et al. (2010). Phase I trial of intraperitoneal administration of an oncolytic measles virus strain engineered to express carcinoembryonic antigen for recurrent ovarian cancer. Cancer Res., 70(3):875-882.

\title{
KIẾN THỨC-THỰC HÀNH VỀ Y ĐỨC CỦA DIỀU DƯỠNG VIÊN BÊ̂NH VIỆN PHỔI TỈNH PHÚ THỌ NĂM 2019
}

\author{
Trần Như Nguyên ${ }^{1}$, Lê Anh Hải, Nguyễn Thị Hồng Hà ${ }^{2}$ \\ Phạm Bá Nhất, Đinh Ngọc S $\tilde{y}^{3}$
}

\section{TÓM TẮT}

Nghiên cứu tiến hành trên toàn bộ 40 điều dưỡng viên Bệnh viện Phổi tỉnh Phú Thọ năm 2019, nhằm mô tả thực trang kiến thức và thực hành về $Y$ đức của họ, kết quả cho thây: Về Kiến thức đạt mức tốt(các tiều chí ở mức 76,7-100\%) trong đó có những tiêu chí rất cao : $95 \%$ hiểu về sẵn sàng giúp đõ chia sẻ với đồng nghiệp; 97,5\% về bảo vệ danh dự đồng nghiệp, $90 \%$ về người bệnh được quyền biết về bệnh của mình,

\footnotetext{
${ }^{1}$ Trường Đại Họ Y Hà Nôi

²Bênh viện Phổi tỉnh Phú Thọ

${ }^{3}$ Trường Đại hoc Thành Đông Hải Dương

Chịu trách nhiệm chính: Phạm Bá Nhất

Email: banhat001@gmail.com

Ngày nhận bài: 15/11/2020

Ngày phản biên khoa hoc: $5 / 12 / 2020$

Ngày duyệt bài: 16/12/2020
}

được giải thích, được lựa chọn kỹ thuâtt chăm sóc. Tuy nhiên còn $10 \%$ cho rằng bệnh nhân không được quyền chọn điều dưỡng viên chăm sóc cho mình; 3,3\% không biết nghề điêuu dưỡng có phù hợp với bản thân không. Về Thực hành đạt mức khá tốt (các tiêu chí ở mức $50-100 \%$ ) trong đó có những tiêu chí rất cao: $97,5 \%$ thực hện tốt việc chiu trách nhiêm về hành vi chuyên môn; $100 \%$ trung thực trong sử dụng thuốc và vật tư tiêu hao. Nhưng còn đến $50 \%$ điều dưỡng viên không hỏi thêm người bệnh các bệnh liên quan; chỉ $40 \%$ có giới thiệu tên và nều lý do tiếp xúc, chỉ $30 \%$ có chú ý tới tâm trạng người nhà người bệnh và $20 \%$ không hỏi lý do người bệnh đến khám

Tư khóa: Kiến thức, thực hành, y đức

\section{SUMMARY \\ KNOWLEDGE, PRACTICE ON MEDICAL ETHICS OF NURSES FROM PHU THO \\ HOSPITAL OF LUNG DISEASE IN 2019}

